\title{
NOTES
}

\section{FOREIGN GOVERNMENT-OWNED CORPORATIONS, THE FOREIGN SOVEREIGN IMMUNITIES ACT, AND THE RIGHT TO JURY TRIAL}

Congress enacted the Foreign Sovereign Immunities Act of 1976 (the Act) ${ }^{1}$ to clarify the law with respect to suits against foreign state defendants in the United States. Before 1976, United States courts used the diversity statute, section 1332 of the judicial code, ${ }^{2}$ as the basis for jurisdiction over foreign state defendants that were not immune from suit. The Act amends the diversity statute to foreclose diversity jurisdiction over foreign states. ${ }^{3}$ At the same time, the Act creates a new section of the judicial code, section 1330, which grants district courts subject matter jurisdiction over "nonjury" civil actions against foreign states in which the claim for relief is "in personam." 4 Most importantly, section 1330 grants district courts jurisdiction in actions

1. Pub. L. No. 94-583, 90 Stat. 2891 (codified at 28 U.S.C. $\S \S 1330$, 1441, 1602-1611 (1976), aunending 28 U.S.C. $\S \S 1332,1391,1441$ ).

2. Before it was ameuded by the Immunities Act, 28 U.S.C. $\S 1332(a)(2)$ (1976), provided as follows: "The district courts shall have original jurisdiction of all civil actions where the matter in controversy exceeds . . \$10,000 . . and is between . . (2) citizens of a State, and foreign states or citizens or subjects thereof...."

3. Section 3 of the Immunities Act amended section 1332(a)(2) by substituting the following language for the language quoted supra in note 2: "(2) citizens of a State and citizens or subjects of a foreign state." It is unclear, however, whether this amendment made it inpossible to Inaintain jurisdiction over foreign corporations under the diversity statute. See infra text accompanying notes 58-76. 28 U.S.C. \& 1332(a)(4) (1976) specifically provides that when a foreign state is a plaimtiff, it can obtam jurisdiction over a United States defendant on diversity grounds. This may imply that Congress intended to foreclose diversity jurisdiction when the foreign government-owned corporation (FGOC) is not the plaintiff.

4. Section 1330(a) provides as follows:

The district courts shall have origimal jurisdiciton without regard to amount in controversy of any nonjury civil action agamst a foreign state as defined in section 1603(a) of this title as to any claim for rehief im personam with respect to which the foreign state is not entitled to immunity either under sections $1605-1607$ of this title or under any applicable international agreement.

28 U.S.C. § 1330(a) (1976). 
against foreign government-owned corporations (FGOCs) ${ }^{5}$ by including FGOCs in its definition of "foreign state."6

The Act's amendment of the diversity statute, its definition of foreign states to include FGOCs, and its reference to "nonjury" actions in granting subject matter jurisdiction raise three questions. First, did Congress intend the Immunities Act to be the sole basis of jurisdiction over foreign defendants? Second, did Congress intend to prohibit jury trial in any action brought under the Act? Finally, if Congress did intend to preclude jury trials, is that preclusion constitutional when the defendant is a FGOC?

This note will explore these questions in detail. First it examines the developments leading up to the Act, analyzes several cases arising under the Act, ${ }^{7}$ and traces the Act's legislative history. ${ }^{8}$ Based on this survey, the note argues that Congress intended the Iminunities Act to be the sole basis of jurisdiction over foreign states and FGOCs and that Congress intended to preclude jury trials in actions involving such defendants. The note then applies the historical test of seventh amendment protection to actions involving defendant $\mathrm{FGOCs}^{9}$ and demonstrates that the part of the Act precluding jury trial in suits involving FGOCs is unconstitutional. The note concludes that the Act should be amended to clarify Congress' intent and to allow jury trial of FGOC defendants. ${ }^{10}$

5. This note refers to corporations owned by foreign governments as FGOCs, not as "foreign states," despite the definition of foreign states that Congress adopted in the Act, see infra note 50.

6. 28 U.S.C. $\$ 1603$ (1976). For the text of the statute, see infra note 50. This definition departs from judicial precedents. Courts have long been reluctant to grant immunity to foreign government-owned commercial corporations. The volume of imternational trade is simply too great to allow government-owned corporations to conduct their businesses free from the possibility of legal sanctions. See Alfred Dunhill of London, Inc. v. Cuba, 425 U.S. 682, 701-05 (1976):

In their commercial capacities, foreign governments do not exercise only those powers peculiar to sovereigns. Instead, they exercise only those powers that can also be exercised by private citizens. Subjecting them in connection with sucl acts to the same rules of law that apply to private citizens is unlikely to touch very sharply on "national nerves."

Id. at 704; see also Petrol Shipping Corp. v. Kingdom of Greece, 360 F.2d 103, 110 (2d Cir.), cert. denied, 385 U.S. 931 (1966); Victory Transp., Inc. v. Comisaria Gen., 336 F.2d 354, 360 (2d Cir. 1964), cert. denied, 381 U.S. 934 (1965); Premier S.S. Co. v. Embassy of Algeria, 336 F. Supp. 507, 510 (S.D.N.Y. 1971); Ocean Transp. Co. v. Government of Republic of Ivory Coast, 269 F. Supp. 703, 705 (E.D. La. 1967).

7. See infra text accompanying notes 11-81.

8. See infra text accompanying notes 82-92.

9. See infra text accompanying notes 93-116.

10. This note does not clrallenge the traditional rule of international law that a sovereign government performing "public acts" is immune froin suit in the courts of foreign nations. For a 


\section{The History, Structure, AND Interpretation of The ACT}

\section{A. The History of Foreign Sovereign Immunity.}

Two theories in international law address the immunity of one state to the judicial process of another: the absolute theory of immunity and the restrictive theory of immunity. ${ }^{11}$ Under the absolute theory, now perhaps espoused only by the Soviet Union and its satellite states, ${ }^{12}$ one state cannot exercise jurisdiction over another without the other's consent. ${ }^{13}$ Under the restrictive theory, claims arising out of a state's "public" acts nuay not be adjudicated, but claims based on the state's "private" acts may be adjudicated. ${ }^{14}$ Private acts are those involving commercial transactions. ${ }^{15}$ Public acts are those of a governmental nature. ${ }^{16}$

The Umited States officially adopted the restrictive theory in $1952^{17}$

discussion of this and related issues, see Lauterpacht, The Problem of Jurisdictional Immunities of Foreign Statcs, 28 BRIT. Y.B. INr'L L. 220 (1951).

11. See Sweeney, The International Law of Sovereign Immunity (U.S. Dep't State Policy Research Study (1963)). See generally, von Mehren, The Foreign Sovereign Immunities Act of 1976, 17 Colum. J. Transnat'L L. 33 (1978).

12. The Soviet Union and its satellite states often claim absolute immunity in international disputes. von Mehren, supra note 11, at 38 n.21.

13. Id. at 34. The absolute theory prevailed in international law until about 1900. Id. The United States judicially adopted the absolute theory in 1812. See The Scliooner Exchange v. McFadden, 11 U.S. (7 Cranch) 116 (1812).

14. Alfred Dunhill of London, Inc. v. Cuba, 425 U.S. 682, 701-06 (1976); see H. R. REP. No. 1487, 94th Cong., 2d Sess. 7, reprinted in 1976 U.S. CoDE CoNG. \& AD. News 6605, 6606 [hereinafter cited as HouSE REPORT]; von Mehren, supra note 11, at 36-43; Note, Sovereign Immunity of States Engaged in Commercial Activities, 65 Colum. L. Rev. 1086, 1094-98 (1965).

15. See Alfred Dunhill of London, Inc. v. Cuba, 425 U.S. 682, 695-98 (1976); New York v. United States, 326 U.S. 572, 579 (1946); Ohio v. Helvering, 292 U.S. 360, 369 (1934); Sloan Shipyards v. United States Fleet Corp., 258 U.S. 549, 567-68 (1922); see also von Mehren, supra note 11 , at 33-34.

For an example of a private act, see Petrol Shipping Corp. v. Kingdoin of Greece, 360 F.2d 103, 106 (1966), im which a FGOC entered into a contract to ship grain from the United States to Greece; see also Bank of the United States v. Planters' Bank of Ga., 22 U.S. (9 Wheat) 904 (1824), in which the Supreme Court denied Georgia's claim of sovereign immunity in a suit arising out of its operation of a banking business. The court found that the banking business constituted a private act: "As a nember of a corporation, a government never exercises its sovereignty. It acts merely as a corporator, and exercises no other power in the management of the affairs of the corporation, than are expressly given by the incorporatmg act." Id. at 908.

16. See Alfred Dunhill of London, Inc. v. Cuba, 425 U.S. 682, 695-98 (1976); Rovin Sale Co. v. Socialist Republic of Rom., 403 F. Supp. 1298, 1302 (N.D. Ill. 1975); Sea Transp. Corp. v. The S/T Manhattan, 405 F. Supp. I244, 1246 (S.D.N.Y. 1975).

Examples of public acts include expulsion of aliens, naturalization, acts involving armed forces, diplomatic activity, and public loans. See Victory Transp. Inc. v. Comisaria Gen. de Abastecimientos y Transportes, 336 F.2d 354, 360 (2d Cir. 1964), cert. denied, 381 U.S. 934 (1965).

17. Many other governments have adopted this position. See Alfred Dunhill of London, Inc. v. Cuba, 425 U.S. 682,702 n.15 (1976). 
when the State Department ${ }^{18}$ issued a letter-the Tate Letter ${ }^{19}$-to the Justice Department informing it of the decision. Following the adoption of the restrictive theory, United States courts began to deny immunity to foreign states when the acts challenged were of a purely commercial nature. ${ }^{20}$ Although the Tate Letter contained specific guidelines, the United States' handling of foreign sovereigns in its courts was defective im inany respects. For example, under the doctrine of Ex Parte Peru, ${ }^{21}$ both the State Department and the courts had the power to decide whether to grant immunity. ${ }^{22}$ To remedy this and similar problems, Congress passed the Foreign Sovereign Immunities Act in 1976.

The principal objective of the Immunities Act is to codify the restrictive theory of sovereign immunity as it has developed in international law and to ensure that the theory will be applied uniformly in United States courts. Stated broadly, the purpose of the Act is "to facilitate and depoliticize litigation against foreign states and to minimize

18. The State Department became involved in determining immunity when courts, adhering less and less to the absolute theory of immunity, began to defer to its advice on whether to grant immunity. See House REPORT, supra note 14, at 6606; see, e.g., Republic of Mex. v. Hoffman, 324 U.S. 30, $35-38$ (1945); Ex Parte Peru, 318 U.S. 588 (1943); Victory Transp., Inc. v. Comisaria Gen. de Abastecimientos y Transportes, 336 F.2d 354, 360 (2d Cir. 1964); see also Cardozo, Judicial Deference to State Department Suggestions: Recognition of Prerogative or Abdication to Usurper?, 48 CORNELL L.Q. 461 (1963).

19. 26 DeP'T STATE Bull. 984 (1952). Tate was the acting legal advisor to the State Department. His letter informed the Justice Department that the United States would follow the restrictive theory of immunity in considering grants of immunity to foreign sovereigns sued by United States citizens. See von Mehren, supra note 11, at 36-43.

20. von Mehren, supra note 11, at 41 . See supra note 6 and cases cited therein (explaining courts' reluctance to grant immunity to FGOCs specifically).

21. 318 U.S. 578, 588-89 (1943). The Court recognized the practise of allowing a foreign sovereign to request that its legal problems be solved through diplomatic channels.

22. von Mehren, supra note 11 , at 41 . A defendent foreign state could litigate its defense of sovereign immunity in court, or it could ask the State Department to decide the question. If the State Department recommended inmunity, the court would automatically defer to this decision, following the inandate of Ex Parte Peru, 318 U.S. 578, 589 (1943). This put the State Department in a difficult diplomatic situation: it became "a pohtical institution trying to apply a legal standard to hitigation already before the courts." HOUSE REPORT, supra note 14, at 6607 ; see a/so Cardozo, Sovereign Immunity: The Plaintiff Deserves a Day in Court, 67 HaRv. L. REv. 603 (1954); Collins, The Effectiveness of the Restrictive Theory of Sovereign Immunity, 4 ColuM. J. TRANSNAT'L L.119 (1965); Comment, Restrictive Sovereign Immunity, the State Department, and the Courts, 62 Nw. U.L. REV. 397 (1967).

By way of contrast, some nations apply international law to determme whether to grant immunity to a foreign state. In those countries diplounatic considerations play no part in the decision. See House REPORT, supra note 14 at 6608 . Because no statute specifically governed suits against foreign states, there was no definitive standard to determine the vahidity of a sovereign immunity defense in the United States. In addition, United States claimants had no way to execute a judgment against a foreign state. See HOUSE REPORT, supra note 14, at 6605; see also Note, Sovereign Immunity of States Engaged in Commercial Activities, 65 CoLUM. L. REV. 1086, 1094-95 (1965). 
irritations in foreign relations arising out of such litigation."23 To achieve this purpose, the Act provides that the judicial branch alone shall determine foreign sovereign immunity. ${ }^{24}$

\section{B. The "Commercial Activities" Exception to Foreign Sovereign Immunity.}

Under the Immunities Act, a foreign state is immune from process in United States courts ${ }^{25}$ unless the state's actions on which the suit is based fall into one of the designated exceptions to immunity. ${ }^{26}$ If the number of cases arising under an exception is indicative of its significance, ${ }^{27}$ the most significant exception to immunity is that for "commercial activities having a nexus with the United States."28 The commercial activities exception applies in three types of cases: ${ }^{29}$ coinmercial activities carried on by a foreign state in the United States, ${ }^{30}$ commercial activities conducted elsewhere but connected with an act

23. House REPORT, supra note 14, at 6605-06.

24. Id. at 6606; see also von Mehren, supra note 11, at 45 .

25. Although the broad policy of the Immunities Act is that a foreign state is immune when a suit is brought against it, the foreign state must plead sovereign immunity as an affirmative defense. The burden of proving immunity therefore rests on the defendant foreign state. HousE REPORT, supra note 14 at 6616.

26. 28 U.S.C. \& 1605 (a) (1976) excepts the following cases from the jurisdictional immunity of the Act:

(1) [those] in whicl the foreign state has waived its immunity either explicitly or by implication ... .

(2) [those] in which the action is based upon a commercial activity carried on in the United States by the foreign state; or upon an act performed in the United States in connection with a commercial activity of the foreign state elsewlere; or upon an act outside the territory of the Umited States in connection with a commercial activity of the foreign state elsewhere and that act causes a direct effect in the United States;

(3) [those] in which rights in property taken in violation of international law are in issue and that property exchanged for sucli property is present in the United States in connection with a commercial activity ... or that property ... is owned or operated by an agency or imstrumentality of the foreign state . . . engaged in a commercial activity in the United States;

(4) [those] in which rights in property in the Urnited States acquired by succession or gift or rights in immovable property situated in the United States are in issue; or

(5) [those] not otherwise encompassed in paragrapls (2) above in whicls money damages are sought against a foreign state for personal injury or death, or damage to . . property, occurring in the United States and caused by the tortious act or omission of that foreign state or of any official or employee of that foreign state while acting within the scope of his office or employinent.

27. See infra note 104 (cases cited), for examples of cases arising under the Act.

28. 28 U.S.C $\$ 1605(a)(2)$ (1976). For the text of that section of the Act, see supra note 26.

29. See id.

30. For example, the legislative history mentions the following activities:

commercial transactions performed in whole or in part in the United States, . . business torts occurring in the United States . . ., and an indebtedness incurred by a foreign state whicls negotiates or executes a loan agreement in the United States, or which receives financing from a private or public lending institution located in the United States.

HOUSE REPORT, supra note 14, at 6615-16. 
performed in the United States, ${ }^{31}$ and commercial acts outside the United States that have a direct effect in the United States. ${ }^{32}$

Most cases that raise the jury trial issue ${ }^{33}$ have been based on the commercial activity of a corporation that is owned partially or entirely by a foreign government-a FGOC.34 FGOCs are defined by the lin1nunities Act as foreign states, ${ }^{35}$ and as such they are apparently entitled to the advantage of a nonjury trial. ${ }^{36}$ Nevertheless, it is possible that because their activities will almost always fall into the commercial activities exception, these FGOCs will never be protected by the restrictive theory of immunity, which is the basis of the Immunities Act.

Thus, the Act has created a class of foreign states-FGOCs-that are ostensibly protected by foreign sovereign immunity. Yet it has also inade an exception to that immunity that includes almost any act a FGOC could perform, thus n1aking it almost impossible to accord FGOCs immunity. Finally, it has arguably denied the right to jury trial in any suit in which immunity does not exist. By legislative fiat, Congress may have precluded jury trial for a class of defendants that inay never qualify for immunity under the Immunities Act. This result is not only illogical, it is inconsistent with Congress' treatment of corporations owned by the United States government.

\section{United States Government-Owned Corporations and Jury Trial.}

Although suits against both foreign and domestic sovereigns were unknown to the common law, ${ }^{37}$ it has been the practice in United

31. The legislative history gives examples of this type of activity: "an act in the United States that violates U.S. securities laws or regulations; the wrongful discharge in the United States of an employee of the foreign state who has been employed in connection with a coininercial activity carried on in some third country." HOUSE REPORT, supra note 14, at 6617-18.

32. The legislative history states that this situation "would embrace commercial conduct abroad having direct effects within the United States which would subject such conduct to the exercise of jurisdiction by the United States consistent with . . Restatement of the Law, Second, Foreign Relations Law of the United States (1965)." Id. at 6618.

33. See infra text accompanying notes 58-80 and note 104 for a discussion of these cases.

34. See, e.g., Rex v. Cia. Pervana de Vapores, S.A., 660 F.2d 61, 62 (3d Cir. 1981), cert. denied, 102 S. Ct. 1971 (1982); Ruggiero v. Conpania Peruana de Vapores Inca Cepac Yupangui, 639 F.2d 872, 873 (2d Cir. 1981); Goar v. Contpania Peruana de Vapores, 510 F. Supp. 737, 738 (E.D. La. 1981).

35. See 28 U.S.C. \& 1603(b)(1) (1976).

36. Defining FGOCs as foreign states in the Inmunities Act brings them within the purview of the Act and forces courts to deal with the "nonjury" language of the Act's subject inatter jurisdiction provision. See supra note 4. If a court determines that it has jurisdiction over a FGOC only under the Act, and that the Act requires nonjury trial, the other party-litigant is denied a jury trial. See Rex v. Cia. Pervana de Vapores, S.A., 660 F.2d 61, 65 (3d Cir. 1981), cert. denied, 102 S. Ct. 1971 (1982); Ruggiero v. Compania Peruana de Vapores Inca Cepac Yupangui, 639 F.2d 872, 875 (2d Cir. 1981); see also infra text accoinpanying notes 67-81.

37. See infra note 108 and accompanying text. 
States courts that suits against commercial corporations owned by the United States are tried before a jury. For exainple, in Panama Railroad Co. v. Curran ${ }^{38}$ and Panama Railroad Co. v. Minnix, ${ }^{39}$ the courts ruled that the Railroad could be sued like any other corporation even though the United States was its sole stockholder. Both suits involvcd personal injury claims and both were tried before juries. ${ }^{40}$

The National Railroad Passenger Corporation (Amtrak) is similar to the FGOCs that are often the subject of suit in the United States. Amtrak's stock is owned entirely by the United States government. ${ }^{41}$ It is supported by federal appropriations and by federally guaranteed loan funds. ${ }^{42}$ By statute, however, Amtrak is not an agency or establishment of the United States government. ${ }^{43}$ Therefore, claims against Amtrak may be tried before a jury. Thus, when an instrumentality of the Urited States government is in reality a commercial enterprise, actions against it niay be tried by jury. Although it would seen reasonable for Congress to treat FGOCs in the saine manner, it appears that Congress has chosen to preclude jury trials of FGOCs.

\section{The Jury Preclusion Issue.}

FGOCs, whose actions are not likely to be immune under the Act because of the commercial activities exception, ${ }^{44}$ are often involved in litigation that traditionally warrants jury trial.45 Thus, it is important to determine conclusively whether the plaintiff in a suit against a FGOC has the right to a jury trial under the Immunities Act. The United States plaintiff may demand a jury trial, hoping that American jurors will be nore synpatlietic to his cause than to that of the foreign defendant. The foreign defendant will probably resist such a demand,

38. 256 F. 768 (5th Cir. 1919). The Curran court stated that "[f]rom the fact that one owns all the stock of a private corporation it does not follow that the acts of the corporation are to be treated, not as its acts, but as acts of its sole stockholder." Id. at 772.

39. 282 F. 47 (5th Cir. 1922). Significantly, the court stated that the "liability of the Panama Railroad Company to suit, as any other railroad company, and its property to seizure, is not affected by the fact that the United States is the sole stockholder." Id. at 49.

40. See Curran, 256 F. at 772; Minnix, 282 F. at 51 (appellate court imphes that lower court judgment was by jury).

41. 45 U.S.C. $\$ 541$ (1976).

42. 45 U.S.C. $\$ \$ 541,601,602,621$ (1976). See generally Adams, The National Railroad Passenger Corporation-A Modern Hybird Corporation Neither Private nor Public, 31 Bus. LAw. 601 (1976).

43. 45 U.S.C. $\$ 541$ (1976).

44. For a discussion of this exceptiou, see supra notes 26-34 and accompanying text.

45. Tort and contract claims, traditionally recognized as legal in nature, are common claims against FGOCs, see infra note 104 (cases cited), and there is a seventh amendment right to jury trial in actions based on legal claims seeking legal remedies, see infra text accompanying notes 96116. 
fearing juror prejudice in favor of the United States plaintiff. ${ }^{46}$

Ascertaining the state of the law concerning the plaintiff's request for a jury trial when the defendant is a foreign state requires unraveling a complex statute. The hitigation that has arisen under the Act evidences the confusion surrounding the issue of jury preclusion and the judicial response reveals a diversity of opinion on the issue. To clarify the jury preclusion issue, it is necessary to examine the statutory changes made under the Act, the case law interpreting these changes, and the legislative history of the Act.

1. Statutory Changes Affecting the Right to a Jury Trial. Before the Act, the federal district courts had diversity jurisdiction in all civil actions involving inore than $\$ 10,000$ when the controversy was between "citizens of a State, and foreign states or citizens or subjects thereof." 47 The Innnunities Act significantly alters the diversity statute by providing for jurisdiction when the controversy is between "citizens of a State and citizens or subjects of a foreign state." 48 The change thus deletes the category of "foreign states" from those litigants who qualify as parties in a diversity suit, apparently foreclosing diversity-in which jury trial is not precluded-as a basis for jurisdiction over cases involving foreign states.

The Act's subject matter jurisdiction provision gives district courts original jurisdiction over nonjury civil actions against foreign states involving in personam claims for which the foreign state is not entitled to immumity under the Act. ${ }^{49}$ The Act's definition of a foreign state includes not only the foreign state government, but also its political subdivisions, agencies, and instrumentalities. ${ }^{50}$ The Act then defines an agency or instrumentality as any entity "which is a separate legal per-

46. See Note, Ruggiero v. Compania Peruana de Vapores and Rex v. Cia. Pervana de Vapores: Jury Preclusion in Actions Against Foreign Sovereign-owned Instrumentalities, 20 Colum. J. Transnat'l L. 199 (1981).

47. 28 U.S.C. $\$ 1332(a)(2)$ (1976) (emphasis added). For the complete text of the former statute, see supra note 2.

48. 28 U.S.C. $\$ 1332(a)(2)(1976)$. For the text of the amended diversity statute, see supra note 3.

49. 28 U.S.C. $\$ 1330$ (a) (1976). For the text of this provision, see supra note 4.

50. 28 U.S.C. $\S 1603$ (1976). That statute provides as follows:

For purposes of this chapter- (a) A "foreign state" . . . mcludes a political subdivision of a foreign state or an agency or instrumentality of a foreign state as defined im subsection (b).

(b) An "agency or instrumentality of a foreign state" means any entity-

(1) which is a separate legal person, corporate or otherwise, and (2) which is an organ of a foreign state or pohtical subdivision thereof, or a unajority of whose shares or other ownership interest is owned by a foreign state or political subdivision thereof, and

(3) which is neither a citizen of a State of the United States . . . nor created under the laws of any third country. 
son, corporate or otherwise."s1 This definition allows the treatment of wholly government-owned corporations as foreign states for purposes of the Act.52

A final statutory change relatimg to the jury trial issue is the addition of section 1441(d) to the judicial code. 53 Section 1441(d) allows actions against foreign states to be removed from state to federal court. This section also provides that removed actions are to be tried by the court, with no right to a jury trial. ${ }^{54}$

The statutory changes appear to preclude jury trials in section 1330 cases involving foreign states. The removal of the words "foreign state" from the diversity statute indicates that Congress wanted to avoid the bringing of suits agamst foreign states under a provision that allows jury trial. ${ }^{55}$ The new removal statute demonstrates that Congress did not intend such actions to be tried by a jury after they are removed from state to federal court.56 Clearly, the drafters of the Act would make no distmction between removed and original actions with regard to the jury issue; 57 therefore, they must have intended that both types of actions would not be tried to a jury. On its face, the Immunities Act precludes jury trial.

2. Judicial Interpretation of the Act. Several cases have examimed the language of the Act. One of the first was Icenogle v. Olympic Airways. ${ }^{58}$ The Icenogle court interpreted the Act to preclude jury trial but apparently believed that denial of jury trials in cases against for-

51. Id. $\S 1603(\mathrm{~b})(1)$.

52. The courts have applied this provision in several cases. See, e.g., Rex v. Cia. Pervana de Vapores, S.A., 660 F.2d 61, 64 (3d. Cir. 1981), cert. denied, 102 S. Ct. 1971 (1982); Ruggiero v. Compania Peruana de Vapores Inca Cepac Yupangui, 639 F.2d 872, 875 (1981); Wilhauns v. Shipping Corp. of India, 489 F. Supp. 526, 528 (E.D. Va. 1980), affd, 653 F.2d 875 (4th Cir. 1981), cert. denied, 102 S. Ct. 1490 (1982); Herman v. El Al Isr. Airlines, 502 F. Supp. 277, 278 (S.D.N.Y. 1980).

53. 28 U.S.C. § 1441(d) (1976) provides as follows: "Any civil action brought in a State court against a foreign state as defined in section 1603(a) of this title may be removed by the foreign state to the district court . . . . Upon removal the action shall be tried by the court without jury."

54. Id. Courts havc relied on this provision in holding that there is no right to jury trial under the Act. See Rex v. Cia. Pervana de Vapores, S.A., 660 F.2d 61, 64 (3d Cir. 1981), cert. denied, 102 S. Ct. 1971 (1982); Herman v. El Al Isr. Airlines, 502 F. Supp. 277,279 (S.D.N.Y. 1980).

55. Jury trial is available under both the diversity statute (28 U.S.C. $\S 1332$ (1976)) and the federal question statute (28 U.S.C. § 1331 (1976)).

56. See supra notes 53-54 and accompanying text.

57. See Houston v. Murmansk Shipping Co., 667 F.2d 1151, 1154 (4th Cir. 1982). That court stated that "[b]ecause the jurisdiction of a district court over an action brought against a foreign state is the same whether the action is commenced in federal court or removed from a state court, we conclude that the text of $\$ 1441$ (d) inore clearly expresses congressional intent than $\$ 1330$ (a).

58. 82 F.R.D. 36 (D.D.C. 1979). Icenogle involved wrongful death actions arising out of a commercial airliner crash. The plaintiffs were United States citizens and the defendant was a corporation owned by the Greek government. 
eign states would violate the seventh amendment. The court examined the diversity statute which, as modified by the Act, ${ }^{59}$ provides that plaintiffs may sue "citizens or subjects of a foreign state," and concluded that the defendant FGOC fell into that category. ${ }^{60}$ The court therefore allowed a jury trial ${ }^{61}$ and avoided the jury preclusion issue.

The Icenogle court based its conclusion on a highly technical construction of the Immumities Act. The Act confers jurisdiction when the defendant is a foreign state. Chapter 97, section 1603 of the Act defines the term "foreign state." 62 This definition is cross-referenced to chapter 85 , section 1330, the section of the Act conferring jurisdiction. ${ }^{63}$ There is no similar cross-reference to section 1332 , the diversity statute. The court noted that the definition states that it is "[f]or purposes of this chapter"; that is, chapter $97 .{ }^{64}$ The court reasoned that because section 1332 is not in chapter 97, the phrase "citizens or subjects of a foreign state" in that section is unaffected by the definition in section 1603 . Therefore, a defendant may be subject to suit under both the Immunities Act and the diversity statute. ${ }^{65}$ The court concluded that if Congress had intended to deny jury trials to Umited States citizens suing "foreign government-owned cominercial corporations" under the diversity statute, it could have imcluded an express provision to that effect in the Immuinities Act. ${ }^{66}$

In Ruggiero v. Compania Peruana de Vapores Inca Cepac Yupangui, ${ }^{67}$ which also involved defendant FGOCs that met the section 1603 definition of foreign states, ${ }^{68}$ the court reached the opposite result: it concluded that Congress intended the Act to be the sole basis for jurisdiction over foreign states. The plaintiffs had argued that a FGOC may be classified as a citizen or subject of the foreign state and is thus amenable to suit under the diversity statute. They based their

59. See supra notes $47-48$ and accompanying text.

60. 82 F.R.D. at 37.

61. Id.

62. 28 U.S.C. $\$ 1603$. See supra note 50 for the text of this provision.

63. 28 U.S.C. $\$ 1330$. See supra note 4 for the text of this provision.

64. See supra note 50.

65. 82 F.R.D. at 38 . The court supported its decision by noting that the case was an original action, not a removal action. The Act clearly precludes jury trial when the action is removed; an original action is not such a clear-cut case. Id. Compare this rationale with the reasoning in Ruggiero, see infra text accompanying notes 67-76.

66. 82 F.R.D. at 39.

67. 639 F.2d 872 (2d Cir. 1981). This case involved claims for damages for personal injuries. The plaintiffs brought suit under the Longshoremen's and Harbor Workers' Compensation Act (LHWCA), 33 U.S.C. \& 905(b).

68. The three defendants in the case were shipping coinpanies wholly owned by their respective governments: Peru, Poland and Indonesia. 639 F.2d at 873. Thus, they were foreign states under $\$ 1603(b)(2)$, see supra note 50. 
argument, similar to that of the plaintiffs in Icenogle, ${ }^{69}$ on the long accepted maxim that a corporation is a citizen or subject of the state that granted its charter. ${ }^{70}$ Accordingly, a plaintiff should have the choice to sue the foreign corporation either as a "foreign state" under section 1330 of the Immunities Act, or as a "citizen or subject of a foreign state" under section 1332, the diversity statute. ${ }^{71}$ The Ruggiero court rejected this argument, reasoning that the same entity "cannot be both a foreign state and a citizen or subject of a foreign state."72 The court explained that considering foreign corporations to be citizens of their states of incorporation was a fiction to facilitate suits against such corporations. ${ }^{73}$ That fiction, according to the court, was niade unnecessary by the Immunities Act. The court viewed the "foreign state" definition in section 1603 of the Act as conclusive on the issue of how FGOCs are to be treated. Thus, under Ruggiero, FGOC defendants are treated like foreign states: they nay be sued only under the Immunities Act.

The Ruggiero court found further support in section 1441(d), the removal statute, for its conclusion that the Immunities Act is the only basis of jurisdiction over FGOCs. ${ }^{74}$ The court reasoned that Congress could not logically have intended to deny jury trial-as does the removal statute-when the action is renroved to federal court, and allow it when the action origmates in federal court. ${ }^{75}$ Allowing suit under section 1332 would create this anomalous situation. The court concluded that the Immumities Act adds a third category to the existing federal jurisdictional bases: actions against foreign states. ${ }^{76}$

Plaintiffs have also atteinpted to avoid the Act's prohibition against juries by claiming jurisdiction under the federal question statute. In Rex v. Cia. Pervana de Vapores, S.A. ${ }^{77}$ the Court of Appeals for the Third Circuit overturned a district court decision allowing suit against FGOCs under the federal question statute. ${ }^{78}$ The district court

69. See supra text accompanying notes 58-65.

70. 639 F.2d at 875.

71. Id. As in Icenogle, the plaintiff would have had the right to a jury trial under the diversity statute.

72. Id. at 875 .

73. Id. The traditional view was that because the shareholders of a corporation were citizens or subjects of a foreign state, the corporation itself was a citizen or subject of the state. The suit was actually agaimst those shareholders. Id.

74. Id. at 877-78.

75. Id. at 876 n.7.

76. Id. at 876 .

77. 660 F.2d 61 (3d Cir. 1982), cert. denied, 102 S. Ct. 1971 (1982). This case, like Ruggiero, see supra note 67 , involved claims for personal injuries and was brought under the LHWCA.

78. The federal question statute provides as follows: "The" district courts shall have original jurisdiction of all civil actions wherein the matter in controversy exceeds the sum or value of 
had concluded that because Congress had not amended the federal question statute when it passed the Immunities Act, it had left an alternative basis for jurisdiction over foreign states when the claim is based on a law, a treaty, or the Constitution of the United States.79 The Court of Appeals for the Third Circuit decided that although Congress "could have stated [it] with nore elegance," its intent was to make the Immunities Act the exclusive basis for jurisdiction when foreign states are defendants. ${ }^{80}$

Although the inajority is not overwhelming, ${ }^{81}$ most courts interpret the Immunities Act in accordance with Ruggiero and Rex, holding that Congress intended the Act to be the only basis for jurisdiction over a FGOC. The Icenogle court makes the strongest argument for the minority position, emphasizing that Congress could have explicitly renioved FGOCs fron the scope of the diversity statute if it so intended. Nevertheless, the stranied reasoning the court had to eniploy to reach what it viewed as the constitutionally correct result demonstrates the weakness of the Act's approach to the jury trial issue. Although Congress failed to express clearly its intentions with regard to jury trial, the statutory changes and the judicial response to the Immunities Act indicate that Congress meant to preclude jury trials in actions under the Act. The legislative history supports this conclusion.

3. Legislative History of the Act. Congress intended section 1330 to be a "conprehensive jurisdictional scheme" for cases involving foreign states. ${ }^{82}$ Congress inuddled this schenie, however, by introducing the jury issue into its grant of subject matter jurisdiction. ${ }^{83}$ The Act's reference to jury trials could be interpreted to mean that Congress intended that only those actions traditionally tried to the court could be brought under the Act. If this interpretation were correct, a court would have to dismiss for lack of jurisdiction actions brought under the Act if it found they should be tried before a jury, ${ }^{84}$ unless it could gain

$\$ 10,000 \ldots$ and arises under the Constitution, laws, or treaties of the United States . . . 28 U.S.C. § 1331(a) (1976) (emphasis added).

79. See Rex v. Cia. Pervana de Vapores, S.A., 493 F. Supp. 459, 469 (E.D. Pa. 1980), rev'd, 660 F.2d 61 (3d Cir. 1982), cert. denied, 102 S. Ct. 1971 (1982).

80. $660 \mathrm{~F} .2 \mathrm{~d}$ at 64 .

81. Of the fourteen cases that have considered requests for jury trial under the Act, see infra note 104 (cases cited), eleven have demied jury trial and three have granted it.

82. House RePORT, supra note 14, at 6611 . When the Act was passed, the House bill was adopted in lieu of the Senate bill. House REPORT, supra note 14, at 6605 . For this reason, the House Report is the legislative history examined here.

83. See supra note 4 for the Act's definition of subjcct matter jurisdiction.

84. See Smit, The Foreign Sovereign Immunities Act of 1976: A Plea for Drastic Surgery, 1980 Proc. Am. Sec'y Int'l L. 49, 57. 
jurisdiction on an alternative ground. ${ }^{85}$ This interpretation, however, is unsupported by the legislative history, and has not been adopted by any court.

The alternative interpretation is that Congress, in linking the jury issue to subject matter jurisdiction, intended to preclude jury trial in all actions against foreign states. This interpretation leads to the conclusion that Congress intended jurisdiction over foreign states to be based only on the Immunities Act, because the other bases for federal jurisdiction do not preclude jury trial. ${ }^{86}$ Indeed, the use of the word "comprehensive" in the legislative history ${ }^{87}$ may indicate that Congress intended that the other possible bases for federal jurisdiction in these cases, diversity and federal question jurisdiction, would not apply. Neither the Act nor the legislative history, however, explicitly states that these other bases of jurisdiction are no longer available for actions against foreign state defendants. ${ }^{88}$ In fact, the House Judiciary Coinmittee report does not inention the federal question statute, but it specifically discusses the diversity statute. The report states that the passage of the Immunities Act inakes a similar jurisdictional basis for foreign states under the diversity statute "superfluous." 89 The Committee did not, however, declare that the Act preempts the diversity statute.

In the Committee's only reference to the jury trial issue, it inerely compares suits against foreign states to suits against the United States, ${ }^{90}$ boldly asserting that jury trials are excluded under the Act. ${ }^{91}$ The committee report does not reveal discussions on the constitutionality of such an exclusion. This omission demonstrates that there was

85. The judge would find diversity jurisdiction or federal question jurisdiction if the complaint in the case alleged facts sufficient to support such jurisdiction.

86. As discussed above, see supra text accounpanying notes 67-80, this interpretation has been adopted by some courts. See, e.g., Rex v. Cia. Pervana de Vapores, S.A., 660 F.2d 61 (3d Cir. 1981), cert. denied, 102 S. Ct. 1971 (1982); Ruggiero v. Coinpania Peruana de Vapores Inca Cepac Yupangui, 639 F.2d 872 (2d Cir. 1981); Williams v. Shipping Corp. of India, 653 F.2d 875 (4th Cir. 1981).

87. See HOUSE REPORT, supra note 14, at 6611.

88. In Icenogle v. Olympic Airways, 82 F.R.D. 36, 38 (D.D.C. 1979), the court held that because Congress was not explicit about whether the Act was to be the sole basis of jurisdiction, it could inaintain jurisdiction under the diversity statute.

89. HOUSE REPORT, supra note 14, at 6613 . In examining this part of the legislative history, the court in Rex v. Cia. Pervana de Vapores, S.A., 660 F.2d 61 (3d Cir. 1981), cert. denied, 102 S. Ct. 1971 (1982), stated that "the FSIA discloses a clear intention to withhold jury trial in all actions against foreign states. . ." Id at 65 . The court went on to conclude that the Immunities Act provides the only basis for jurisdiction over foreign state defendants. Id. . For a discussion of the plaintiff's argument in Rex that jurisdiction should be based on the federal question statute, see supra text accoinpanying notes 77-80.

90. See House RePort, supra note 14, at 6611 .

91. Id. 
hittle, if any, contemplation of the effects of this part of the Act. The report also reveals that the Committee did not consider whether designating FGOCs as foreign states would give them the privilege of protection from jury trials. It simply stated that its reason for precludmg jury trials was to promote "uniformity in decision," avoiding comphicated foreign relations problems. ${ }^{92}$ The Committee apparently decided that jury verdicts would be imconsistent and that this inconsistency might offend foreign states. By failing to draft the Act in clear language, the Committee left the courts to deal with the effect of the Act on the seventh amendment right to jury trial.

\section{The Unconstitutionality of Precluding Jury Trials WhEN FGOCs ARE DeFENDANTS}

Whether Congress may preclude jury trials of FGOC defendants is subject to debate. ${ }^{93}$ This note argues that such preclusion is unconstitutional. FGOCs are "foreign states" only because the Immunities Act so defines them. They are in reality commercial corporations that should not receive the protection traditionally accorded to foreign sovereigns. Therefore, jury trial should be available in an action against a FGOC if a jury trial would be available agamst some other defendant.

Since the early days of the British empire, trial by jury has been a cherished right in the common law system. ${ }^{94}$ Blackstone observed that the Magna Carta msisted on it as "the principal bulwark of our liberties."95 The United States has followed this tradition. The seventh amendment to the Uinted States Constitution guarantees the right to trial by jury in suits at common law. ${ }^{96}$ In determining the scope of the seventh amendment, then, the question is, what is a suit at common law? In Parsons v. Bedford, ${ }^{97}$ the Supreme Court of the United States shed hight on this question:

By common law, they [the writers of the amendment] meant . . not merely suits which the common law recogmized among its old and settled proceedings, but suits in which legal rights were to be ascertamed and determined, in contradistinction to those where equitable

92. Id. at 6612 .

93. See Note, supra note 27 (concluding that the Act's preclusion of juries is constitutional).

94. See, e.g., 2 JONE's BLACKSTONE \& 459a.

95. Id; see also Beacon Theatres v. Westover, 359 U.S. 500, 501 (1959).

96. The seventh amendment provides as follows:

In suits at common law, where the valne in controversy shall exceed twenty dollars, the right of trial by a jury shall be preserved; and no fact tried by a jury shall be otherwise reexamimed in any Court of the United States, than according to the rules of the common law.

U.S. Const. amend. VII.

97. 28 U.S. (3 Pet.) 474 (1830). 
rights alone were recognized, and equitable remedies were administered . . .98

The traditional determination of whether an action is triable to a jury has therefore been whether the claim is legal. Legal claims are triable to a jury; equitable claims are triable to the court. ${ }^{99}$ As to what makes a claim legal, the Supreme Court in Scott $v$. Neely ${ }^{100}$ stated that "[a]ll actions which seek to recover . . . a money judgment for breach of a simple contract, or as damages for injury to person or property, are legal actions . . . ."101 More recently, the Court in Pernell v. Southall Realty" 102 noted that it "has long assumed that actions . . . for dainages to a person or property . . . are actions at law triable to a jury." 103 For purposes of analyzing the Act's preclusion of jury trial of FGOCs, the question is whether actions against FGOCs are capable of legal reinedy. If a legal reinedy exists in any action, then it inust be tried before a jury.

In each of the fourteen cases in which a plaintiff suing a FGOC has requested a jury trial, the defendant "foreign state" has been a commercial entity. ${ }^{104}$ The most common claims inade against these de-

98. Id. at 79.

99. C. Wright, LaW of Federal Courts 450 (1976).

100. 140 U.S. 106 (1891). Scott v. Neely was a suit in equity in which a creditor sought to reach certain property im payment of a contract debt. The Court held that the claim was cognizable only at law and could not be brought in an equity action. Id. at 117; see also Pernell v. Southall Realty, 416 U.S. 363, 370 (1974) (quoting Whitehead v. Shattuck, 138 U.S. 146, 15I (1891)).

10I. 140 U.S. at 110 .

102. 416 U.S. 363 (1974). Pernell dealt with the question whether trial by jury is guaranteed in an action to recover possession of real property. Southall Realty attempted to evict Pernell from his residence for alleged nonpayment of rent. Id. at 363. The Court held that the right to jury trial must be preserved in actions such as this one where common law rights and remedies are involved. Id. at 383 .

103. Id. at 370. The Supreme Court has jealously guarded the right to jury trial in civil actions. In Dairy Queen v. Wood, 369 U.S. 469 (1962), for exainple, the Court rejected the contention that the presence of a basic equitable issue deprives the litigant of the right to a jury trial on the legal issues presented. Id. at 477. Dairy Queen involved an action alleging breach of a licensing contract. The lower courts denied the defendants' request for jury trial on the ground that plaintiffs' requests for an injunction and an accounting were equitable. The Suprene Court leld, however, that "[a]s an action on a debt allegedly due under a contract, it would be difficult to conceive of an action of a more traditionally legal character." Id. at 477. The Court allowed jury trial, relying on language in Beacon Theatres, Inc. v. Westover, 359 U.S. 500 (1959), which states that if a claim is properly cognizable at law, then every effort should be made to preserve the right to jury trial. A mixture of equitable and legal claims is not, therefore, sufficient reason for denying jury trial. Id. at 510.

104. See Rex v. Cia Pervana de Vapores, S.A., 660 F.2d 61, 62 (3d Cir. 1981) (jury trial demed), cert. denied, 102 S. Ct. 1971 (1982); Williams v. Shipping Corp. of India 653 F.2d 875 (4th Cir. 1981) (jury trial denied), cert. denied, 102 S.Ct. 1490 (1982); Ruggiero v. Counpania Peruana de Vapores Inca Cepac Yupangui, 639 F.2d 872, 873 (2d Cir. 1981) (jury trial denied); Alvarez v. National Shipping Corp., No. 80-491, shp op. (S.D.N.Y. Oct. 2, 1982) (jury trial demed); Goar v. 
fendants were in tort or contract. 105 The tort or contract claimant usually seeks damages or some other inoney judgment: a legal remedy. Thus, the plaintiff with a tort or contract claim against a FGOC has a legal action that meets the historical test for seventh amendment protection. The plaintiff is therefore entitled to a jury.

Congress ${ }^{106}$ and soine courts ${ }^{107}$ have concluded, however, that because suits against a foreign sovereign as well as the domestic sovereign, the Umited States, were unknown to the common law courts of $1791,{ }^{108}$ the preclusion of jury trial under the Immunities Act is justified even though the result is that plaintiffs suing FGOCs are denied jury trials. A similar argument was rejected, however, in Curtis v. Loether. ${ }^{109}$ In Curtis, the plaintiff brought suit for injunctive relief and punitive damages under section 812 of the Civil Rights Act of 1968. The district court denied the defendant's request for a jury, holding that jury trial was neither authorized by Title VIII nor required by the seventh amendment. ${ }^{110}$ The plaintiff's argument against jury trial was that the seventh amendinent does not apply to "new causes of action created by congressional enactment."111 The Supreme Court rejected this argument, holding that the seventh amendment apphies to "actions enforcing statutory rights, and requires a jury trial upon demand, if the statute creates legal rights and remedies, enforceable in an action for

Companie Peruana de Vapores, 510 F. Supp. 737, 738 (E.D. La. 1981) (jury trial denied); Rapaport v. Banco Mexicano Somex, No. 80-435, slip. op. (N.D.N.Y. Nov. 25, 1980) (jury trial demed); Herman v. El Al Isr. Airlines, 502 F. Supp. 277, 278 (S.D.N.Y. 1980) (jury trial denied); Houston v. Murmansk Shipping Co., 87 F.R.D. 71 (D. Md. 1980) (jury trial granted), vacated, 667 F.2d 1151 (4th Cir. 1982) (denying jury trial); Cucullu v. M/V Odessa, No. 78-3344 (E.D. La. Apr. 28, 1980) (unpublished order) (jury trial denied); Lonon v. Companhia de Vavegacao Lloyd Basiliero, 85 F.R.D. 71, 72 (E.D. Pa. 1979) (jury trial granted); DiMartino v. S.C. India Corp., No. 75-1485 (E.D.N.Y. Nov. 20, 1979) (unpublished order) (jury trial denied); East Europe Domestic Int'1 Sales Corp. v. Terra, 467 F. Supp. 383, 384 (S.D.N.Y.) (jury trial denied), affd, 610 F.2d 806 (2d Cir. 1979); Icenogle v. Olympic Airways, 82 F.R.D. 36, 37 (D.D.C. 1979) (jury trial granted); Outboard Marime Corp. v. Pezetel, 461 F. Supp. 384, 388-89 (D. Del. 1978) (jury trial denied).

105. See supra notes 58-80 and accompanying text (discussing Icenogle, Ruggiero, and Rex) and note 104 (cases cited).

106. See House ReP., supra note 14, at 6611 .

107. See Rex v. Cia. Pervana de Vapores, S.A., 660 F.2d 61, 69 (3d Cir. 1981), cert. denied, 102 S. Ct. 1971 (1982); Ruggiero v. Compania Peruana de Vapores Inca Cepac Yupangui 639 F.2d 872, 881 (2d Cir. 1981).

108. Herman v. El Al Isr. Airlines, 502 F. Supp. 277, 280 (S.D.N.Y. 1980) (and authorities cited therein); accord Ruggiero v. Compania Peruana de Vapores Inca Cepac Yupangui, 639 F.2d 872, 879 (2d Cir. 1981).

109. 415 U.S. 189 (1974).

110. Id. at 191.

111. Id. at 193. 
damages in the ordinary courts of law."112

Plaintiffs with legal claims against FGOCs are denied seventh amendment protection by the Immunities Act chiefly because such defendants qualify, under a technical definition, as "foreign states."113 Many of these defendants are owned by foreign governments; often, however, this ownership is a reflection of the political and social structure of their countries. ${ }^{114}$ It is a characteristic of socialist governments that business and industry are owned by the state. ${ }^{115}$ This political difference between the United States and many of the countries it trades with should not work against United States litigants suing commercial entities that have broken contracts or committed torts. ${ }^{116}$

\section{CONCLUSION}

Congress, through the Foreign Sovereign Immunities Act, attempted to provide a comprehensive procedure by which litigants could prosecute claims against foreign states. In its zeal, Congress failed to consider carefully the language in which it framed this procedure. Its grant of subject matter jurisdiction does not clearly indicate whether the Act is the sole basis for jurisdiction over foreign states. ${ }^{117}$ The weight of authority and the legislative history indicate tliat without debate or consideration of the constitutional implications of its action,

112. Id. at 194. Although the Court acknowledged that Congress can create administrative procedures and remedies where jury trial is not required, it emphasized the importance of jury trials in ordinary civil actions:

But when Congress provides for enforcement of statutory rights in an ordimary civil action in the district courts, where there is obviously no functional justification for denying the jury trial right, a jury trial must be available if the action mvolves rights and remedies of the sort typically enforced im an action at law.

Id. at 195.

113. See 28 U.S.C. § 1603 (1976).

114. See Rabinowitz, Can the Court Cope with the Foreign Sovereign Immunities Act?, 1 N.Y.L. SCH. J. INT'L \& CoMP. L. 131, 132-33 (1980).

115. See Timberg, Sovereign Immunity, State Trading, Socialism and Self-Deception, 56 Nw. U.L. REv. 109, 111-13 (1961) (discussing the paradox of socialistic governments and foreign sovereign immunity).

116. Evcn when absolute sovereign immumity was the rule in United States courts, FGOCs were not presumed to be immune. As corporations, they were private party litigants, and if they chose to assert immumty as a dcfense it had to be claimed by an agent of the sovereign. Kunglig Jarnvagsstyrelsen v. Dexter \& Carpenter, Inc., 300 F. Supp. 891, 892-93 (S.D.N.Y. 1924), affd, 32 F.2d 195 (2d Cir. 1929). If immumity was granted, it was only after consideration of the nature of the action. In Oliver Am. Trading Co. v. Mexico, 5 F.2d 659 (2d Cir. 1924), the court found that the action was only nommally against the National Railways of Mexico. It was "in reality a suit only against the Mexican government." Id. at 661 . Thus, the court granted immumity. The Mexican government operated the railroad as it would any government agency. The scope of the Immunities Act is inuch broader, causing the issue of sovereign immumity to turn, in many instances, on inere stock ownership.

117. See supra notes $82-92$ and accompanying text. 
Congress apparently intended to preclude jury trial in cases brought under the Act. ${ }^{118}$

An application of the historical test for seventh amendment protection demonstrates that a bar to jury trials in these cases is unconstitutional. ${ }^{19}$ United States citizens deal regularly with foreign corporations or their products. ${ }^{120}$ The Immunities Act denies these citizens the protection of their own constitution simply because the corporations with which they deal are partially or wholly owned by a foreign government.

Congress should amend the Act to correct these deficiencies. The mention of jury trial in the Act itself is an error. Courts have no choice but to deny jury trial in cases agamst a FGOC because the Act incorporates jury preclusion as a prerequisite to jurisdiction. ${ }^{121}$ One solution to this dilemma is to remove the language concerning juries from the Act. This action would leave judges free to consider the merits of allowing jury trial in particular cases. ${ }^{122}$ Another solution is to add to the Act a provision allowing jury trial in suits under the Act if the defendant is a FGOC. ${ }^{123}$

The best solution, however, is to remove FGOCs from the Act's definition of "foreign state." The Act would then provide for immunity in any situation in which a FGOC performs public acts, thus protecting the FGOC if it does in fact function as a sovereign. ${ }^{124}$ This solution preserves the Immunities Act preclusion of jury trial in actions against foreign sovereigns. It also allows courts to treat FGOCs conductimg commercial acts as they would any other litigant and avoids the constitutional deficiencies now present in the Act.

Kimberly K. Hill

118. See supra notes 58-92 and accompanying text.

119. See supra text accompanying notes 93-116.

120. HOUSE RePORT, supra note 14, at 6605 .

121. See Smit, supra note 84, at 57. For the text of the subject matter provision, section 1330(a), see supra note 4.

122. The decision whether to recognize a claim of immunity would be made before the action reached a jury. House REPORT, supra note 14, at 6616 . The foreign state would therefore not be subject to a jury trial on the issue of immunity.

123. Such a provision might resemble the Amtrak statute. See supra text acconipanying note 43.

124. It is difficult to imagine what acts by a FGOC could be classified as public, see supra note 16 (examples of public acts); therefore, a FGOC would rarely be grantcd immunity under the proposed revision of the Act. 